\title{
English Language Skills Required by the Hospitality and Tourism Sector in El Oro, Ecuador
}

\author{
Mayra Alexandra Cuenca Erazo \\ Universidad Técnica de Machala, Machala, Ecuador \\ Stephanie Isabel Molina Ramírez \\ Universidad Técnica de Machala, Machala, Ecuador \\ Maria Asuncion Rojas Encalada \\ Universidad Técnica de Machala, Machala, Ecuador \\ Jhonny Villafuerte Holguin \\ Universidad Laica Eloy Alfaro de Manabí, Manta, Ecuador \\ Jia Hui Zou \\ Universidad Técnica de Machala, Machala, Ecuador
}

\begin{abstract}
- the present study follows a qualitative research approach that analyzes the perceptions of people linked to the different fields in the tourism sector of the province of El Oro in Ecuador. Currently, this province has professionals who lack a good level of English proficiency to provide foreigners with the best service. The researchers applied semi-structured interviews, capitalization of testimony, and focus group discussions to 15 participants associated with the different activities in the tourism area. The present study aimed to explore the needs and uses of the English language in the tourism and Hostelry sectors of "El Oro," the implications of having staff with good English language knowledge, and the impact of knowing English in the tourism sector. The results revealed that staff required having an appropriate level of English proficiency to make tourists feel comfortable during their stay. For this reason, knowing English has a positive impact in all the areas of the tourism sector. The researchers suggest further studies regarding the effectiveness of different strategies and techniques to develop English for Tourism Purposes (ETP) at the university level and examine the impact of knowing English in the different fields of the tourism sector.
\end{abstract}

Index Terms-English Language Skills, English for Specific Purposes, English for Tourism Purposes, competencies, techniques, service

\section{INTRODUCTION}

Nowadays, there is a lack of professionals with enough English skills to function correctly in the tourism sector of the Ecuadorian province of El Oro. For this reason, the authors conducted the present qualitative study to explore the opinions of the participants about the needs for being able to communicate in English.

Machala is the capital of the province El Oro, and it is principally known for its agricultural activities. Tourism was not the central aspect as it is now, which it has evolved through time thanks to the improvements in the urban areas, transport, and the creation of restaurants, bars, shopping centers, among others.

It is important to note that in 2018 the Tourism Minister has revealed that within the principal markets of visitors to Ecuador are the United States, Canada, and Germany, which most of them lack the knowledge of the local language.

For the present study, the researchers applied the qualitative approach to analyze the opinions of 15 participants from the province of El Oro who are linked in the tourism sector. The participants were five owners of tourism establishments, five professionals who graduated from an Ecuadorian University in El Oro, and five professors who specialized in Tourism from an Ecuadorian University in the province of El Oro. To undertake the analysis of this qualitative research, the authors aim to answer the following research questions:

1. What are the needs and uses of the English language in the tourism and Hostelry sectors of "El Oro," Ecuador?

2. What are the implications of having staff with good English language knowledge?

3. What is the impact of knowing English in the tourism sector? 
In order to answer these research questions, the authors reviewed previous studies to support the data obtained from semi-structured interviews, focus group discussions, and capitalization of testimony applied to the contributors of the present research.

The results revealed that knowing English has a positive impact on all the activities of the tourism sector. The authors recommend further research regarding the effectiveness of different strategies and techniques to develop ETP at the university level.

\section{LITERATURE REVIEW}

\section{A. The Contribution of Using the English Language in the Development of the Hospitality and Tourism Sector around the World}

English is a vital aspect in the tourism sector since it allows providing the best service to foreign visitors who do not know the local language. Furthermore, tourism professionals need to speak English to foreigners to make their visit more enjoyable (Pupo Ferras, Faedo-Borges, \& Ortigoza Garcell, 2012). People who are required to use English at work for tourism and hospitality purposes need to improve their communicative abilities, language fluency, and accuracy (Zahedpisheh \& Abu Bakar, 2017). This language is taught as a second language in educational institutions of various levels since it is a significant element to establish communication with others worldwide (Seidlhofer, 2005).

Concerning Ecuador, In 2016, 1.617.014 visitors came to this country, which demonstrates that the country is a real tourism potential. More than 1, 6 million foreigners came to Ecuador in 2017, obtaining the 14\% increment in respect to 2016, this according to the Tourism Minister is "good news" (Ponce de León, 2018). Over the years the figures have been increasing in this area as the result of arduous work on the part of the ministry of tourism, who has demonstrated a high capacity to increase visitors to the country through extensive advertising worldwide (Ministerio del Turismo, 2017).

In Ecuador, tourism is positioned every year as a potential product for the economy of the country, knowing that in the year 2017 there were 1,663 million dollars in foreign currency income, which means a growth of 14.8\% concerning the previous years. Therefore, this sector is recognized as one of the most important for the economy of the country (Ministerio de Turismo, 2017).

\section{B. Best Rated Competencies in the Tourism Sector}

Among the competencies currently required in the work environment of tourism, specific competencies of the professional area that have been stimulated by higher academic education is the ability to express fluently in English (Avalos \& Zapata, 2014).

Qualified human talents are required to improve the Ecuadorian tourism sector. So, efficient communication in English is essential to improve professional profiles (Villafuerte, Benitez and Franco, 2017). Likewise, tourism is an important economic sector that is continually changing and evolving as a result of globalization and innovation.

All these changes are having an impact on the human resources of the sector and on the required professional competences, being competences in Information and Communication Technologies (ICT) and linguistic competences those that seem to be most demanded by employers (Garcia Manjon \& Perez Lopez, 2008, page 71).

While according to the analysis of Prachanant (2012), when tourism employees were asked to choose three functions of knowledge of the English language that is used mainly in their work, the results revealed that among the most relevant functions were giving information, followed by the rendering of services, and offering help to problems.

The authors Bosch Abarca and Giménez Moreno (2001) argue that when the specialists of the tourism sector face the communicative needs of their customers, they realize that the best way to satisfy the expectations of the consumer is the ability to capture the subjective, emotional and physical needs that stimulate the success of the transaction.

\section{Linguistic Skills Required by the Professional in the Tourism Sector}

A study conducted in the tourist labor market of Puerto Lopez of the Province of Manabi in Ecuador to find out the English proficiency of the employees of the tourism sector, applied surveys to a population constituted by five hotel companies and three tourism agencies. The results indicated that people had seen the need to optimize and master English as it allows them to improve their performance in work activities (Tigua Anzules, Lucas Marcillo, \& Azúa Menéndez, 2017).

Within the requirements to provide an excellent service, English appears as a mandatory requirement to communicate with future customers. For this reason, the development of language skills is essential for a good communication process (Bobanovic \& Grzinic, 2011).

A study conducted by Prachanant (2012) about the needs of English and its use in the tourist industry, revealed that when Tourism employees were asked to assess their need for English language skills to function appropriately at work, they rated all four language skills, but speaking turned out to be more important, followed by listening, reading and writing.

However, in a detailed analysis by Prachanant (2012), it evidences the following outstanding problems in the workplace when they accompany foreign tourists to visit tourist attractions throughout Thailand. 
- Regarding the ability to listen, employees cannot understand the accents of foreigners, followed by the consideration that according to employees, foreign tourists talk too fast.

- Regarding the problems to speak, the most severe problem is the use of inappropriate words and expressions to speak followed by a lack of knowledge of grammar and structure.

- Regarding reading problems, the main one has an inadequate vocabulary in reading followed by the fact that they cannot understand the vocabulary.

- Among the problems encountered when writing, is the lack of grammar knowledge.

1. the significance of Speaking and Listening in Hotel Operations

English is considered for workers in the hotel area as a complement to achieve greater labor efficiency since those who master the language can generate greater profitability to the organization (Gómez de Lunar, 2009).

English is an essential aspect of the reception and reservations area. The skills of speaking and listening are applied together in essential activities, such as making reservations by phone (Leslie \& Russell, 2006).

Regarding Ecuador, following the legal housing reform, the regulation that controls the tourism activity of accommodation at the national level and is part of the tourism regulations issued in 2016, the transitional provision establishes that tourist accommodation establishments should have staffs who speak at least a foreign language (Ministerio de Turismo, 2016).

2. the Significance of Writing and Reading for Residential marketing and intermediary tourist services (Travel Agencies, Operators)

The use of English is often used in intermediary companies such as travel agencies and operators. In the case of communication, it is essential to be able to maintain a dialogue about a service. Employees should be able to perform an internal task. For example, creating a tourist package, and for this, they must have good reading and writing skills since in most cases communication with companies that are in other countries are given by emails (Kostic Bobanovic $\&$ Grzinic, 2011).

Marketing and advertising is an essential tool in the tourism sector because thanks to this there is the possibility of transmitting an image and information about a tourist place. In this area, the use of English is essential since it is necessary to know terminologies and advanced English to attract future tourists (Korstanje, 2014).

3. the use of English skills in scientific research related to tourism

English in the scientific area has more scope than any other language since the most significant amount of research and updates on various tourism topics are mostly in English. That is why in the case of students or teachers, the latest publications in scientific journals help to improve the teaching process as it conveys the newest events on issues regarding tourism. In the case of teachers, they need English, specifically for consultations on the subject they are teaching and being informed of new trends on a specific topic.

Likewise, if they wish to transmit their point of view reflected in an article, the implementation of writing and reading are essential to carry out this work (Niño-Puello, 2013). The reading ability used in scientific articles helps both the knowledge of new topics in tourism and in the same way to the comprehension of texts, improvement in grammar, writing, and vocabulary (Carvajal, 2014).

\section{Techniques to Improve Linguistic Skills for Future Tourism Professionals}

\section{Role-Plays}

According to Rojas (2018), the use of role-plays allows teachers to evaluate the speaking abilities of learners. To that end, ESP practitioners need to identify the causes that interfere in the participation of communicational activities, and perform actions that will lead students "to learn more vocabulary, have more grammar control, and become more fluent, less shy, more encouraged, and more capable to pronounce words correctly" (Rojas, 2018, p. 49).

\section{Self-Video Recording}

Another study conducted by Soto, Espinoza, Vargas, Cajamarca, Fontaine, and Carrera (2017), analyzes the insights of ESP students towards the recording of videos to explain class content. The results of this study revealed that participants' perceive that there is an improvement in motivation and academic achievement. Furthermore, they develop self-regulated strategies, self-awareness of their learning development, and self-regulated environmental strategies, which show a beneficial influence of the strategy for the language learning progress. Students live experiences of metacognition detecting their errors and applying strategies to improve their speaking in the use of the foreign language (Farfan et al., 2017).

3. Collaborative Work through Technological Means

A study conducted by Rojas, Villafuerte, and Soto (2017), which was aimed to improve learners' English writing production through cooperation and technological means revealed that students' efforts and time to develop writing skills has a direct relationship with the learners' interests. As a result, the combination of collaborative work and technological resources improve the development of the written communicative competence. Specifically, the improvements were focused on the development of technical vocabulary, writing style, and writing coherence. Besides, the scholars Villafuerte, Intriago and Romero (2018) presented a didactic tool that combines multiple creative activities and relies on the virtual social networks for the execution of reading and comprehension practices in the professional training context. 


\section{E. Training or Preparation of Tourism Staff and Future Tourism Professional}

1. Teaching English for Tourist Purposes (ETP)

According to Richards (2001), a useful language program merits the consideration of factors that go beyond the mere content and presentation of teaching materials, such as sociocultural factors, teaching and learning styles, factors related to the student (attitudes, interests, learning habits, etc) as cited in (Pupo Ferras, Faedo Borges, \& Ortigoza Garcell, 2012).

Globally tourism has been evolved into one of the largest economic sector contributing 35\% of the global exports of services (UNWTO, 2008). UNWTO also predicted 1.6 billion international tourist arrivals worldwide by 2020 which shows the growth potential of the tourism sector throughout the world. Tourism plays a vital role in GDP and employment. According to the World Tourism and Travel Council 2006 report, tourism contributed 6.3\% to GDP and $5.1 \%$ for job creation in Pakistan (WTTC 2006).

More and more employees who work in tourism realize the importance of English. Consequently, they need to have a good command of English in their workplace, which is a significant role in delivering high-quality service. (Zahedpisheh \& Abu Bakar, 2017). According to Zahedpisheh \& Abu Bakar, English is also divided into different types:

1. English for Tour Managers and Guides

2. English for Air Flight Services

3. English for Food and Beverage Services

In today's globalized world, the English language has become the standardized language for business communication. According to the Ecuadorian Tour Guidance Regulation, Chapter IV of Accreditation, Article 12, a requirement for accredited national tour guidance is to have at least level B1 of a foreign language according to the Common European Framework (TURISMO, 2016).

According to Tosun and Temizkan in the article of (Yavuz Çetinkaya \& Oter, 2016) indicate that tour guides carry great responsibility since it is believed that not only transmit information, but they present it excitingly with excellent command of words and spontaneity.

A tour guide must know the information entirely and when issuing it must know how to do it; therefore the implementation of English is necessary for the skills of a guide, and this must be of a high level to deliver a clear and error-free message avoiding problems in the coding of foreign tourists. A tour guide must be able to hold interesting conversations and explain in a leisurely manner so as not to leave gaps in information (Chehanika Sandaruwani \& Gnanapala, 2016).

Concerning Ecuador, in Chapter IV of the Art. 12 Accreditation, mentions that among the requirements for the accreditation of the national guide of tourism, to accredit at least level B1 of knowledge of one foreign language according to the Common European Framework for Languages, and to the established by this regulation and other provisions issued by the National Tourism Authority (Ministerio de Turismo, 2016).

\section{METHODOLOGY}

\section{A. Participants}

This research uses the qualitative approach to determine the perceptions of 15 participants from the province of El Oro who are connected with activities related to tourism. The participants of this study were composed by five owners of tourism establishments, five professionals who graduated from an Ecuadorian University in El Oro, and five professors who specialized in Tourism from an Ecuadorian University in the province of El Oro.

The criteria for participants' selection are the following:

1. Owners of tourism establishments such as hotels or travel agencies.

2. Tourism professional who graduated from an Ecuadorian university in the Province of El Oro.

3. Professors who are specialized in tourism and teach subjects related to this field from a university in the Province of El Oro.

\section{B. Context}

The study took place in the province of El Oro, which lack professionals who are able to communicate in English in the tourism sector. Therefore, the researchers decided to conduct a qualitative study to find out the perceptions of participants involved in the tourism area in the province of El Oro. The authors sought to find out the opinions of this study's contributors about the needs of being able to communicate in English in the tourism sector.

Nowadays, the city of Machala located in the province of El Oro in Ecuador is developing in tourism, since there have been changes and regenerations in the city which has induced to advances in public and private areas through the attraction of tourists.

About the last newsletter of August 2018, the Tourism Minister demonstrates that within the principal markets are the United States, Canada, and Germany. Therefore, it is vital the use of English for a better service to tourists, since in most cases visitors only have a basic Spanish level (Ministry of tourism, 2018).

\section{Instruments and Data Collection Analysis}


The instruments used in this research were: (1) interview; (2) expert testimonies, and (3) focus group discussions. , and it was validated through the review of experts. Three experts from a public university in the province of Manabi and five experts from a public university in the province of El Oro contributed to the validation process of these instruments. The experts recommended checking the style of questions and vocabulary. The original version of the instrument is in Spanish by the local language.

1. the Interview

The instrument applied is a semi-structured interview to owners of tourism establishments. The purpose of the interview is to learn the opinions of owners of tourism establishments about the significance of having staff with good English knowledge., and it consists of seven semi-structured questions. The instrument was tested in its validity through the Expert Panel integrated by professors of two Ecuadorian public universities. After the experts' evaluation, the instrument was edited and applied to the participants at their workplace.

2. Professional testimonies

The researchers' team designed a format for capitalization of testimonies. The purpose of this instrument is to collect testimonies of tourism professional. , and it consists of seven semi-structured questions. The instrument was tested in its validity through the Expert Panel integrated by professors of two Ecuadorian public universities. After the experts' evaluation, the instrument was edited and applied to the participants at their workplace.

3.-Focus Group Discussion

The purpose of the focus group discussion is to collect information about the impact of knowing English in the tourism sector. The questionnaire applied included seven questions. , and it consists of seven semi-structured questions. The instrument was tested in its validity through the Expert Panel integrated by professors of two Ecuadorian public universities. After the experts' evaluation, the instrument was edited and applied to the participants at their workplace.

\section{Ethical Considerations}

All the participants were asked to sign a Consent Form before taking part in the research. The use of codes protects the participants' identity. In this regard, for the present study, there were three types of participants (tourism establishment owners, tourism professionals, and university professors specialize in tourism). The researchers' team keeps all data for seven years. The data collected can only be used for academic purposes.

\section{RESULTS AND DISCUSSION}

\section{A. Semi-structured Interview}

The interview was applied to owners of tourism and hotel businesses located in the province of "El Oro." The purpose was to collect data to respond to the first research question: What are the needs and uses of the English language in the province of El Oro in the tourism sector?

TABLE 1

NEEDS AND USES OF THE ENGLISH LANGUAGE IN TOURISM AND HOTEL SECTORS IN THE PROVINCE "EL ORO"

\begin{tabular}{|c|c|c|}
\hline Categories & Participants' Responses & Subcategories \\
\hline $\begin{array}{l}\text { English Language } \\
\text { Proficiency }\end{array}$ & $\begin{array}{l}\text { INT.BTAG: "Everything is oral here” [INT-08] } \\
\text { INT.NTAG: "yes. Employees must speak or write depending on the tourist".[INT-029] } \\
\text { INT.DH:" Yes. Because they are usually tourists and they always ask about tourist } \\
\text { attractions and many times they do not know how to speak Spanish".[INT-01] }\end{array}$ & $\begin{array}{l}\text { Advance level. } \\
\text { Intermediate level. } \\
\text { Intermediate to } \\
\text { Advance level. }\end{array}$ \\
\hline $\begin{array}{l}\text { Requiring } \\
\text { Communication } \\
\text { skills in English }\end{array}$ & $\begin{array}{l}\text { INT.BTAG: "Listen and talk to customers" [INT-010] } \\
\text { INT.HTAG: “Reading and speaking are more used here” [INT-017] } \\
\text { INT.NTAG Speaking because employees talk more with customers and you write very } \\
\text { little.[INT-031] } \\
\text { INT.DHT. Once you speak, it means that you understand. [INT-03] }\end{array}$ & $\begin{array}{l}\text { Listening skill. } \\
\text { Reading skill. } \\
\text { Oral skill. } \\
\text { Oral skill. }\end{array}$ \\
\hline $\begin{array}{l}\text { The frequency of } \\
\text { English language use }\end{array}$ & $\begin{array}{l}\text { INT.BTAG: "Not every day you have foreign customers" [INT-011] } \\
\text { INT.HTLAG: "Machala is not a city of foreigners" [INT-018] } \\
\text { INT.PTAG: "There are not many foreigners in the city" [INT-025] } \\
\text { INT.DHT. Here really the frequency is not much, because foreigners do not come } \\
\text { anyway.[INT-04] }\end{array}$ & $\begin{array}{l}\text { Occasionally. } \\
\text { Rarely. } \\
\text { Sometimes. } \\
\text { Rarely }\end{array}$ \\
\hline
\end{tabular}




\begin{tabular}{|c|c|c|}
\hline $\begin{array}{l}\text { Advantages of } \\
\text { knowing English }\end{array}$ & $\begin{array}{l}\text { INT.BTA: “Better communication with customers" [INT-010] } \\
\text { INT.HTLAG: "Fulfill the needs in the computer systems in customer service for giving } \\
\text { tourist information”"[INT-016] } \\
\text { INT.PTAG: "Speaking English increases the company's income"[INT-022] } \\
\text { INT.PTAG: "Being better able to sell the product by speaking with the customers".[INT- } \\
\text { 023] } \\
\text { INT.NTAG: "Getting a wider range of customers" [INT-030] }\end{array}$ & $\begin{array}{l}\text { Communication } \\
\text { with foreign } \\
\text { customers } \\
\text { Communication } \\
\text { with foreign } \\
\text { customers } \\
\text { Income increase } \\
\text { Income increase }\end{array}$ \\
\hline $\begin{array}{l}\text { Disadvantages of not } \\
\text { knowing English }\end{array}$ & $\begin{array}{l}\text { INT.BTAG "Losing a sale because if you do not speak or do not have at least a basic level } \\
\text { of English, you cannot make any business" [INT-012] } \\
\text { INT.HTAG. The lack of communication and the loss of customers.[INT-019] } \\
\text { INT.NTAG. Not being able to communicate with the customers.[INT-033] }\end{array}$ & $\begin{array}{l}\text { Decrease in income } \\
\text { Little } \\
\text { communication is } \\
\text { done with foreign } \\
\text { customers. } \\
\text { Little } \\
\text { communication is } \\
\text { done with foreign } \\
\text { customers. }\end{array}$ \\
\hline $\begin{array}{l}\text { Priority for hiring } \\
\text { employees }\end{array}$ & $\begin{array}{l}\text { INT.BTAG: "It is important because the customers are foreigners" [INT-013] } \\
\text { INT.HTAG: "to be able to deliver a complete and quality service" [INT-020] } \\
\text { INT.NTAG: "Yes. because now foreign tourists are arriving and the cruise ships are } \\
\text { going to start arriving”[INT-034] } \\
\text { INT.DHT: "Yes although, I mention that not many foreigners come here, but it is } \\
\text { necessary to improve the service standards"[INT-06] }\end{array}$ & $\begin{array}{l}\text { Customers need to } \\
\text { communicate in } \\
\text { English. } \\
\text { Qualifications in } \\
\text { tourism service } \\
\text { Customers need to } \\
\text { communicate in } \\
\text { English. } \\
\text { Qualifications in } \\
\text { tourism service }\end{array}$ \\
\hline $\begin{array}{l}\text { Preference for hiring } \\
\text { employees }\end{array}$ & $\begin{array}{l}\text { INT.BTAG: "I prefer the one who speaks English because this person can be trained in } \\
\text { customer service and the work itself, but someone who does not know English would be } \\
\text { more difficult to teach the language"[INT-014] } \\
\text { INT.HTAG: "For me, the most important aspect is to have someone who has experience } \\
\text { because I do not require staff who knows English" [INT-021] } \\
\text { INT.PTAG: "No, in the province it is not necessary to have a higher level of English, but } \\
\text { the experience is necessary" [INT-027] } \\
\text { INT.PTAG: "It depends on the city. In the case of Machala, you need to hire people with } \\
\text { experience, and not necessarily someone who knows English" [INT-028] } \\
\text { INT.NTAG: "I take somebody with experience" [INT-035] } \\
\text { INT.DHT: "I prefer someone with experience because this way guests are satisfied, but I } \\
\text { know that it is necessary to understand and speak English to foreign guests."[INT-07] }\end{array}$ & $\begin{array}{l}\text { Bilingual staff } \\
\text { Work experience } \\
\text { Work experience } \\
\text { Work experience } \\
\text { Work experience } \\
\text { Work experience } \\
\text { Bilingual staff }\end{array}$ \\
\hline
\end{tabular}

\section{Analysis:}

The results ratify the position of Tigua, Lucas, and Azúa (2017) when they affirm that tourism and hotels staff required a good level of English knowledge to establish effective communication with customers. Such condition warranties a better service in comparison to other similar businesses. Thus, the tourist and hotel proprietaries that participated in this research expressed the following perceptions: INT.BTAG: "Everything is oral here" [INT-08]; INT.NTAG: “yes. Employees must speak or write depending on the tourist".[INT-029]; INT.DH:” Yes, because they are usually tourists and they always ask about tourist attractions and many times they do not know how to speak Spanish."[INT-01]

Kostic Bobanovic and Grzinic (2011) maintain that the use of English in travel agencies and tour operators is frequently. According to them, the most used communication skill in travel agencies is writing emails to give information about the services offered or to perform international communication with foreign countries companies or 
potential passengers. The results of the semi-structured interview applied to the owners of establishments related to the tourism sector show the following opinions: INT.BTA: "Better communication with customers" [INT-010]; INT.HTLAG: "Fulfill the needs in the computer systems in customer service for giving tourist information”[INT-016].

However, in the hotel environment, the participants expressed that speaking is the most required skill to give touristic information, explain amenities and facilities policies, checking-in and checking-out services, among others. INT.PTAG: "Speaking English is the best resource to increase the income of the company"[INT-022];INT.PTAG: "Being better able to sell the product by speaking with the customers".[INT-023]; INT.NTAG: "Getting a wider range of customers" [INT-030]. In this respect, the authors ratify the position of Rojas, Villafuerte, and Soto (2018) maintaining that classes that resemble real-life situations in the tourism sector can be an efficient technique used for introducing dialogues related to tourism in ESP training programs.

\section{B. Work Experience and Testimonies of Professionals from the Tourism and Hotel Sectors}

A group of professionals from the tourism and hotel sectors expressed their work experience concerning the implication of knowing English in their workplaces. This activity pretends to respond to the second research question: What are the implications of having staff with good English language knowledge?

TABLE 2

THE IMPLICATION OF ENGLISH KNOWLEDGE IN THE TOURISM AND HOTEL SECTORS IN THE PROVINCE OF EL ORO

\begin{tabular}{|c|c|c|}
\hline Categories & Subcategories & Participants' Responses \\
\hline \multirow{5}{*}{$\begin{array}{l}\text { Time working in the tourism } \\
\text { sector (Labor experience) }\end{array}$} & Overall experience & $\begin{array}{l}\text { CT.CPPROF."I have been working for three years in tourism" } \\
\text { [CAP-036] }\end{array}$ \\
\hline & $\begin{array}{l}\text { Experience in bars and } \\
\text { restaurants }\end{array}$ & CT.BPPROF: 5 years [CAP-043] \\
\hline & Experience in hotels & CT.JGPROF: 3 years [CAP-050] \\
\hline & $\begin{array}{l}\text { Experience as a } \\
\text { specialized guide }\end{array}$ & CT.LCPROF: $a$ year and a half [CAP-057] \\
\hline & Tourist Guide & CT.KCPROF: a year and four months.[CAP-064] \\
\hline \multirow[t]{2}{*}{$\begin{array}{l}\text { Influence of the language } \\
\text { knowledge in the work area }\end{array}$} & $\begin{array}{l}\text { Importance of English } \\
\text { in the tourism sector }\end{array}$ & $\begin{array}{l}\text { CT.CPPROF: "positively influences all the areas that I have } \\
\text { worked". [CAP-037] } \\
\text { CT.JGPROF: "Used to understand foreign tourists". [CAP- } \\
\text { 051] } \\
\text { CT.LCPROF: "Helps to communicate with foreigners and } \\
\text { offer a quality service". [CAP-063] }\end{array}$ \\
\hline & $\begin{array}{l}\text { Importance of English } \\
\text { worldwide }\end{array}$ & $\begin{array}{l}\text { CT.BPPROF: "The language needs are very high, and } \\
\text { English is the most important language worldwide". [CAP- } \\
044]\end{array}$ \\
\hline \multirow[t]{2}{*}{$\begin{array}{l}\text { English language needs } \\
\text { currently }\end{array}$} & $\begin{array}{l}\text { Use of English in hotel } \\
\text { activities }\end{array}$ & $\begin{array}{l}\text { CT.CPPROF: Help Check in and check out guests who do not } \\
\text { speak Spanish. [CAP-038] } \\
\text { CT.JGPROF: Learn the requirements of the guests. [CAP- } \\
\text { 052] }\end{array}$ \\
\hline & Satisfying tourists & $\begin{array}{l}\text { CT.BPPROF: Due to the flow of tourists in the country, we } \\
\text { are likely to use English at any time. [CAP-045] } \\
\text { CT.KCPROF: Not understanding tourists, if English is not } \\
\text { used. [CAP-066] }\end{array}$ \\
\hline \multirow{2}{*}{$\begin{array}{l}\text { Reasons why the English } \\
\text { language has been used }\end{array}$} & Better communication & CT.BPPROF: Provide better customer service. [CAP-046] \\
\hline & Labor activities & $\begin{array}{l}\text { CT.KCPROF: In the workplace (travel agency) with systems } \\
\text { and customers. [CAP-067] }\end{array}$ \\
\hline Language Skills & Speaking and listening & $\begin{array}{l}\text { CT.LCPROF: I consider that the ability of speaking is the } \\
\text { most important in tourism [CAP-059] } \\
\text { CT.KCPROF: ... in a travel agency and guide, in my opinion, } \\
\text { to speak ... [CAP-068] }\end{array}$ \\
\hline
\end{tabular}




\begin{tabular}{|c|c|c|}
\hline & $\begin{array}{l}\text { Generation of a better } \\
\text { work environment }\end{array}$ & $\begin{array}{l}\text { CT.JGPROF: Knowing English helps meet customer } \\
\text { requirements. [CAP-052] }\end{array}$ \\
\hline \multirow[t]{3}{*}{$\begin{array}{l}\text { The frequency of English } \\
\text { use in the workplace }\end{array}$} & Sometimes & $\begin{array}{l}\text { CT.CPPROF: "Not necessarily always, but sometimes it is } \\
\text { used during the week." [CAP-041] }\end{array}$ \\
\hline & Always & $\begin{array}{l}\text { CT.BPPROF: It is always important to use English in the } \\
\text { tourism sector. [CAP-048] }\end{array}$ \\
\hline & Occasionally & $\begin{array}{l}\text { CT.LCPROF: ...our area does not experience massive } \\
\text { tourism [CAP-062] }\end{array}$ \\
\hline \multirow[t]{3}{*}{$\begin{array}{l}\text { Anecdotes about the use of } \\
\text { English in the workplace }\end{array}$} & Checking-in a guest & $\begin{array}{l}\text { CT.CPPROF: The foreign customer needed lodging; } \\
\text { therefore, help him to check in without any problem, thanks to } \\
\text { the language knowledge. [CAP-042] } \\
\text { CT.JGPROF: The tourist was African, and he only understood } \\
\text { English, and I was able to meet his requirements. [CAP-056] }\end{array}$ \\
\hline & $\begin{array}{l}\text { When making a tourist } \\
\text { guidance }\end{array}$ & $\begin{array}{l}\text { CT.BPPROF: The visitors were Asian, and they only spoke } \\
\text { English, and it was a little complicated to understand, but the } \\
\text { situation was controlled. [CAP-049] } \\
\text { CT.LCPROF: a foreign person approached me, but my } \\
\text { English is not so good and it was difficult to understand the } \\
\text { requirements. [CAP-063] }\end{array}$ \\
\hline & In travel agencies & $\begin{array}{l}\text { CT.KCPROF: "At the agency, two people approached me } \\
\text { asking for a tour. It was difficult to sale a package to them } \\
\text { because of the language barrier, but it was done through } \\
\text { translators. After this experience, we became more aware of } \\
\text { the importance of English by enrolling in an English course". } \\
\text { [CAP-070] }\end{array}$ \\
\hline
\end{tabular}

\section{Analysis:}

The study about the implication related to English knowledge on the hotel and tourism industries have led the researchers' team to apply the discipline of integration approach. Thus, the researchers' team agrees with the work of Pupo Ferrás, Faedo Borges, and Ortigoza Garcell (2012) when they affirm that the social-communicative process is developed according to the situational and thematic context. In this case, the use of English in the hotel and tourism sector.

Consequently, the participants expressed their own professional experience as bartenders, hotel staff, travel agent, and tour guide. The data collected allows identifying the impact of knowing English in this sector: CT.CPPROF: "positively influences in all the areas that I have worked". [CAP-037]; CT.JGPROF: "I used English to understand foreign tourists". [CAP-051]; CT.LCPROF: "Helps to communicate with foreigners and offer a quality service". [CAP-063]; CT.BPPROF: "The language needs are very high, this being the most important worldwide". [CAP-044]

The authors agree with Zahedpisheh and Abu Bakar (2017) about the growing number of employees who realize the importance of knowing English in the hotel and tourism sectors. CT.CPPROF: "positively influences in all the areas that I have worked". [CAP-037]; CT.JGPROF: "I used English to understand foreign tourists". [CAP-051]; CT.LCPROF: "Helps to communicate with foreigners and offer a quality service". [CAP-063].

The general agreement among the scholars is that having a good command of English is beneficial in the workplace (Villafuerte, Benitez and Franco, 2017), and it guarantees the delivering of high-quality service in the field of tourism and hotels. In this regard, participant CT.KCPROF stated that "At the agency, two people approached asking for a tour, however, it was difficult to sale the package, but it was done through translators. After this experience, they became more aware of the importance of knowing English by enrolling in an English course”. [CAP-070].

\section{Work Experience and Testimonies of Professionals in the Tourism and Hotels Sectors}

A group of professors from an Ecuadorian public university participated in a focus group discussion, and data were collected to answer the third research question: What is the impact of knowing English in the tourism and hotel sectors? 
TABLE 3

IMPACTS OF KNOWING ENGLISH IN THE TOURISM AND HOTELS SECTOR

\begin{tabular}{|c|c|c|}
\hline Categories & Subcategories & Evidence \\
\hline \multirow{2}{*}{$\begin{array}{l}\text { 1. Time worked in the } \\
\text { tourism sector }\end{array}$} & In travel agencies and teaching & FG.MA: 15 years approximately. [FG-071] \\
\hline & $\begin{array}{l}\text { Experience in restaurant and travel } \\
\text { agency }\end{array}$ & FG.EP: 6 years [FG-072] \\
\hline \multirow[t]{2}{*}{$\begin{array}{l}\text { 2. Influence of knowing } \\
\text { or not knowing the } \\
\text { language in the tourism } \\
\text { sector }\end{array}$} & It has not affected & $\begin{array}{l}\text { FG.MA:" In my reality, I have had no major } \\
\text { inconvenience." [FG-073] } \\
\text { FG.BL: "But, it is imperative to take it into } \\
\text { account since it is the language most used } \\
\text { around the world." [FG-075] }\end{array}$ \\
\hline & In travel agencies & $\begin{array}{l}\text { FG.EP: "It is important to give information } \\
\text { and advice on visas." [FG-074] }\end{array}$ \\
\hline $\begin{array}{l}\text { 3. Tasks that require } \\
\text { knowing the English } \\
\text { language in the province } \\
\text { El Oro. }\end{array}$ & Scientific Research & $\begin{array}{l}\text { FG.NB: "Most of the current information is in } \\
\text { English journals, therefore understanding the } \\
\text { language is important to find information" } \\
\text { [FG-076] } \\
\text { FG.EC: To carry out investigative work.[FG- } \\
\text { 077] }\end{array}$ \\
\hline \multirow[t]{3}{*}{$\begin{array}{l}\text { 4. Most used linguistic } \\
\text { skills in the workplace }\end{array}$} & Speaking and listening & $\begin{array}{l}\text { FG.EP. "I think mainly verbal communication } \\
\text { and listening. However, I do not detract from } \\
\text { reading and writing".[FG-078] }\end{array}$ \\
\hline & Reading & $\begin{array}{l}\text { FG.BL: "Because the systems used in travel } \\
\text { agencies or hotels are mostly in English." } \\
\text { [FG-079] }\end{array}$ \\
\hline & Writing & $\begin{array}{l}\text { FG.EC. ... be able to express thoughts when } \\
\text { writing something. [FG-080] }\end{array}$ \\
\hline $\begin{array}{l}\text { 5.The frequency of } \\
\text { English use in the } \\
\text { workplace }\end{array}$ & Sometimes & $\begin{array}{l}\text { FG.EC. when it is required. [FG-081] } \\
\text { FG.MA. ... in my subjects, there are terms in } \\
\text { which you must understand English.[FG-082] }\end{array}$ \\
\hline
\end{tabular}

\section{Analysis}

More and more employees realize the importance of knowing English especially in businesses related to commerce, tourism, technologies; therefore, these businesses require professionals with a good command of English (Zahedpisheh and Abu Bakar, 2017). Thanks to the urban areas improvements as well as the developments in transport, and the creation of restaurants, bars, shopping malls, and other recreational places. Tourism has evolved in the province of El Oro. FG.MA:” In my reality, I have had no major inconvenience for not knowing the language." [FG-073]; FG.BL: "But, it is vital to take it into account since it is the language most used around the world." [FG-075]; "It is important to give information and advice on visas."

The researchers agree to Prachanant (2012) position about the benefits of knowing English in the twenty-first century as a significant factor to function well in the tourism industry around the world. Thus, the data collected show the following evidence in the same sense:[FG.NB] and [FG.EC] stated that "Most of the current information is in English journals, therefore understanding the language is important to find information."

Avalos and Zapata (2014) affirm that the competencies required in tourism and hotels are related to efficient communication on the use of foreign languages. In this respect, FG.NB: FG.EP mentions "I think mainly verbal communication and listening. However, I do not detract from reading and writing". [FG-078]FG.BL: "Because the systems used in travel agency or hotels are mostly in English." [FG-079]

The researchers of the present study also agree with Yavuz Çetinkaya and Oter (2016), Chehanika Sandaruwani \& Gnanapala (2016) when they insisted that tour guides responsibilities are not only transmitting information but also communicating and interacting with tourists.

\section{CONCLUSION}

This research was carried out in the province of El Oro where professionals in the tourism sector do not manage the English language properly to provide the best service to foreign visitors. Therefore, the researchers conducted a qualitative study to explore the opinions of the participants about the needs for being able to communicate in English. 
Because of Machala's progressive development in the urban area, tourism has become an essential factor that needs to be promoted through focusing on improving English skills in the future professionals of this sector.

In this regard, students who are majoring in tourism need to learn English properly to function effectively in this area. The authors review previous studies on some techniques used at the university level to develop English skills in future tourism professionals.

For the present study, the authors applied the qualitative approach to analyze the perceptions of 15 participants from the province of El Oro who are linked in the tourism sector. The authors suggested three research questions to analyze this qualitative study, which was answered through a review of previous studies to support the information. The authors also applied semi-structured interviews, focus group discussions, and capitalization of testimony to answer the questions.

In regards to the answers of the first question by the owners of tourism and hotel businesses, the collected data revealed that tourism and hotel employees need a good level of English proficiency to provide a good service to customers. This outcome was supported by the findings of Tigua, Lucas, and Azúa (2017) who maintain that in order to keep an effective communication with foreigners; it is required to have a good level of English.

Concerning the use of English, the findings of a study conducted by Kostic Bobanovic and Grzinic (2011) maintain that the use of English in travel agencies and tour operators is frequently, especially writing emails to give information about the services offered or to perform international communication with customers. An example that demonstrates the importance of the use of English in travel agencies was given by INT.HTLAG: "Fulfill the needs in the computer systems in customer service for giving tourist information"[INT-016]. On the other hand, in hotel situations, the answers revealed that speaking is an essential skill to give touristic information, explain amenities and facilities policies, checking-in and checking-out services, etc.

To answer the second research question, the researchers applied a capitalization of testimony to a group of professionals from the tourism and hotels sectors. The outcomes supported the findings of Pupo Ferrás, Faedo Borges, and Ortigoza Garcell (2012) who maintain that social-communicative process is developed according to the situation such as the use of English in the hotel and tourism sector. The participants communicated their experiences working as bartenders, hotel staff, travel agent and tour guide. The collected information identified the influence of knowing English in the tourism sector.

Additionally, The answers of the participants go in hand with the study conducted by Zahedpisheh and Abu Bakar (2017) concerning the increasing number of staff who realize the significance of knowing English in the hotel and tourism sectors. For example, participant CT.LCPROF stated that knowing English "Helps to communicate with foreigners and offer a quality service" [CAP-063].

In connection with the third research question the participants' answers and the findings of Zahedpisheh and Abu Bakar (2017) reveal that employees working in different fields perceive the usefulness of knowing English. In this regard, the participant FG.BL stated that "...it is imperative to take it into account since it is the language most used around the world".

Avalos and Zapata (2014) and the participants' answers agree with the fact that the competencies required in tourism and hotels are linked to adequate communication on the use of foreign languages. In this respect, participant FG.BL stated, “...the systems used in travel agency or hotels are mostly in English". [FG-079]

To sum it all up, from the results of the collected data and the literature review that support it, tourism and hotel staff are required to have an appropriate level of English proficiency to make tourists feel comfortable during their stay and provide the best service. For this reason, knowing English has a positive influence in all the areas of the tourism sector where the staff is capable of following an effective communication process with customers. Since personnel from the province of El Oro recognize the usefulness of knowing English, further studies to measure the effectiveness of different strategies and techniques to develop English for Tourism Purposes at the university level would be necessary to analyze the impact in the different fields of the tourism sector.

\section{ACKNOWLEDGMENTS}

The authors wish to thank the authorities of Universidad Técnica de Machala for the unconditional support to carry out the present research.

\section{REFERENCES}

[1] Avalos, C., \& Zapata, N. (2014). Competencias Requeridas en el Ámbito Laboral del Turismo. FPUNE Scientific, 4, 153-158.

[2] Bobanovic, K. M., \& Grzinic, J. (2011). The importance of English language skills in the tourism sector: A comparative study of students/employees perceptions in Croatia. AlmaTourism 2.4, 10-23.

[3] Bosch, E., Jiménez, R. (2001). Tourist's needs versus student's needs: A pedagogical approach to teaching English for tourism. In S. Posteguillo, I. Fortanet \& J.C. Palmer. (eds.). Methodology and new technologies in languages for specific purposes. Castellón: Universitat Jaume I: 241-249.

[4] Carvajal, A. E. (2014). Importancia y reflexiones sobre la investigación y publicación científica desde pregrado. SCientifica, $12.1,7-8$. 
[5] Chehanika Sandaruwani, R., \& Gnanapala, A. C. (2016). The role of tourist guides and their impacts on sustainable tourism development: A Critique on Sri Lanka. Tourism, Leisure and Global Change, 3, 1-13.

[6] Farfan, G, Villafuerte, J., Romero, A., \& Intriago, E. (2017). Tecnologías de apoyo para el fortalecimiento de las destrezas comunicativas en lenguas extranjeras estudio de caso: filmes cortos producidos por futuros docentes de inglés. PixelbitRevista de Medio y Educación 51, 183-195.

[7] Garcia, J., \& Perez, M. (2008). El grado en Turismo: Un análisis sobre las competencias profesionales. Cuadernos de Turismo $21,67-83$.

[8] Gómez de Lunar, V. (2009). Desempeño laboral del licenciado en turismo de la universidad de oriente, según la opinión del sector empresarial turístico privado de la isla de Margarita, estado nueva Esparta. Gestión Turística 11, 41 - 68.

[9] Korstanje , M. E. (2014). Reseña "Comparative Tourism Marketing Case Studies" de Alexandru Nedelea. PASOS. Revista de Turismo y Patrimonio 12.12, 499-502.

[10] Kostic Bobanovic, M., \& Grzinic, J. (2011). Importance of English language skills in the tourism sector: A comparative study of students/employees perceptions in Croatia. Alma Tourism 4, 10-23.

[11] Leslie, D., \& Russell, H. (2006). The importance of foreign language skills in the tourism sector: A comparative study of student perceptions in the UK and continental Europe. Tourism Management, 27.6, 1397-1407.

[12] Ministerio de turismo (2016). Reglamento de alojamiento Turístico. Quito, Ecuador: Ecuadorian Government Publishing Service.

[13] Ministerio de Turismo. (2016). Reglamento de Guianza Turística. Quito, Ecuador: Ecuadorian Government Publishing Service.

[14] Ministerio de Turismo. (2017). Balanza Turistica 2017, Quito, Ecuador: Ecuadorian Government Publishing Service

[15] Ministerio de Turismo. (2018). Turismo en cifras-Boletin mensual. Quito, Ecuador: Ecuadorian Government Publishing Service.

[16] Niño-Puello, M. (2013). El inglés y su importancia en la investigación científica : Algunas Reflexiones. Revista Colombiana de ciencia, 5.1, 243-254.

[17] Perelló, J. L. (2017). El Turismo en Cuba comienza a recuperarse (Resumen del 1er semestre). Retrieved from https://www.excelenciascuba.com/noticia/el-turismo-en-cuba-comienza-recuperarse-resumen-del-1er-semestre (accessed 10/10/2018).

[18] Ponce de León, E. (2018, April 8). Aproximadamente 1,6 millones de extranjeros llegaron a Ecuador en 2017, según el ministro Ponce de León. El Comercio, pp. 1. Retrieved from https://www.elcomercio.com/actualidad/millones-extranjerosecuador-turismo-economia.html (accessed 10/10/2018).

[19] Prachanant, N. (2012). Needs Analysis on English Language Use in Tourism Industry. Procedia - Social and Behavioral Sciences, 66, 117-125.

[20] Pupo, F., S., Faedo-Borges,A., \& Ortigoza Garcell, C. (2012). Tendencias curriculares del inglés con fines específicos: surgimiento y evolución para el turismo en Cuba. Centro de Información y Gestión Tecnológica de Santiago de Cuba, 18.2, 111.

[21] Randstad (2017). El empleo del sector turístico aumenta un 4,6\% y registra la mayor cifra de la historia. Retrieved from https://www.randstad.es/nosotros/sala-prensa/el-empleo-del-sector-turistico-aumenta-un-46-y-registra-la-mayor-cifra-de-lahistoria/ (accessed 10/10/2018).

[22] Rojas, M. (2018). Role-plays as an assessment tool in English as a Foreign Language (EFL) class. In S.T. Soto, E. Intriago, J. Villafuerte (eds.), Beyond Paper and Pencil Test: Good Assessment Practices for EFL Classes. Machala: Editorial UTMACH, 49-73.

[23] Rojas, M., Villafuerte, J. and Soto, S.T. (2017). Collaborative Work and Technological Means for Improving Learners English Language Writing Production. Turkish Online Journal of Educational Technology. Special Issue for IETC 2017. 385-391

[24] Seidlhofer, B. (2005). English as a lingua franca. ELT Journal, 59.4, 339-341.

[25] Soto, S. T.; Espinosa, L.F.; Vargas Caicedo, E; Illescas; Fontaines-Ruiz, T.; Carrera, D. (2017). How Does Explaining Content Through Videos Benefit Language Learners? Esp Students Tell us About it. Turkish Online Journal of Educational Technology. Special Issue for IETC 2017. 385-391.

[26] Tigua, J., Marcillo, M., \& AzúA, M. (2017). Diagnóstico del dominio del inglés en el mercado laboral turístico de Puerto López. Rev. Cientifica SINAPSIS, vol.1.10, 1-14.

[27] Villafuerte, J., Benitez, R., \& Franco, O. (2018). Formación vocacional y los retos de la educación del siglo xxi. Caso de estudio: Los profesionales en ciencias administrativas de Ecuador. Didasc@lia: Didáctica y Educación, 9.1, 273-284.

[28] Villafuerte, J., Intriago, E., \& Romero, A. (2018). Promoción de la comprensión lectora interactiva en idioma inglés. Revista Refcale, 6.2, 49-69.

[29] Yavuz Çetinkaya, M., \& Oter, Z. (2016). Role of tour guides on tourist satisfaction level in guided tours and impact on revisiting Intention: a research in Istanbul. Open Access, 7, 40-54.

[30] ZahedpishehNahid, \& Abu BakarBZulqarnain. (2017). English for Tourism and Hospitality Purposes. English Language Teaching 10.9, 86-94.

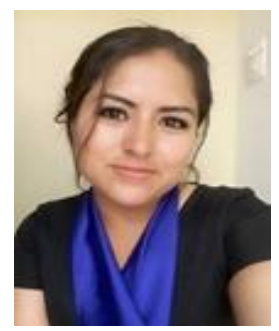

Mayra A. Cuenca was born in 1993 in the city of Piñas located in the Province of El Oro in Ecuador. She is about to get her Bachelor's Degree in Tourism and Hotel Management at Universidad Técnica de Machala (UTMACH).

During her university studies, she has done practical training in the tourism sector such as Travel Agencies and Tourism Operators in the city of Machala. She has also worked in activities related to tourism in the community around the province of El Oro to collect information of the touristic attractions. Nowadays she is a member of a research group at UTMACH called ESP Researchers.

Ms. Cuenca has completed and approved the fifth level of English in a Language Institute at UTMACH. 


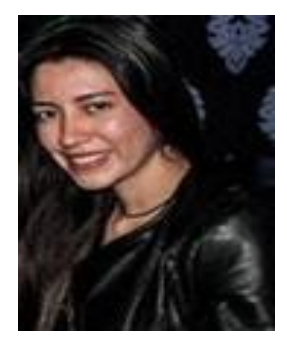

Stephanie I. Molina was born in the city of Piñas located in the Province of El Oro in Ecuador in the year 1996. She is getting her Bachelor's Degree in Tourism and Hotel Management at Universidad Técnica de Machala (UTMACH).

During her university studies, she has been working in the hotel industry to get the full experience of her academic major. She has also worked in activities related to tourism in the community around the province of El Oro to collect information of the touristic attractions. Currently, she is a member of a research group at UTMACH called ESP Researchers to conduct various studies related to her field.

Ms. Molina was awarded the Certificate of Achievement B2 Upper Intermediate provided by Education First in the year 2016 in Toronto, Canada.

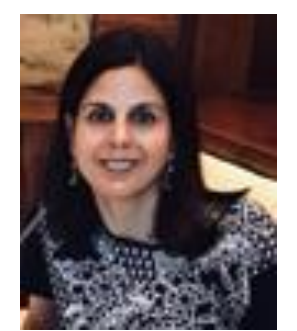

Maria A. Rojas is an Ecuadorian professor and researcher. In the year 2017, she earned a Master's Degree in Teaching English as a Foreign Language at Escuela Superior Politécnica del Litoral (ESPOL) in Ecuador. She is currently studying her Ph.D. in Advanced English Studies at the University of La Coruña, Spain. Her primary field of study focuses on English Language Teaching (ELT). She has been working as an ESP professor at Universidad Tecnica de Machala (UTMACH) in Machala, Ecuador since the year 2014.

Prof. Rojas is a member of a Research Group called ELT Innovators at UTMACH. Some of her recent publications are The Influence of Implementing Role-play as an Educational Technique on EFL Speaking Development (Theory and Practice in Language Studies, 2018). Collaborative Work and Technological Means for improving Learners' English Language Writing Production (Turkish Online Journal of Educational Technology, 2017), Performance-Based Tasks as a Mean to Assess the Speaking of Learners of English as a Foreign Language (Turkish Online Journal of Educational Technology, 2017), and English Language Teaching Approaches: A comparison of the Grammar-Translation, Audio-lingual, Communicative, and Natural Approaches (Theory and Practice in Language Studies, 2017).

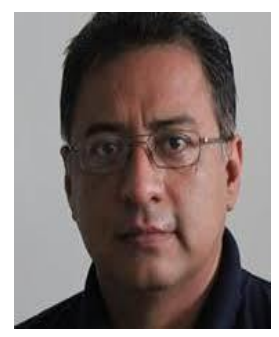

Jhonny S. Villafuerte, Ecuadorian researcher graduated from the Master's Program in Psycho Didactics from the University of the Basque Country, Spain; and from the Master's Program in Educational Research at Universidad Nacional de Loja, Ecuador. Other studies about education and local development were conducted in Chile, Brazil, USA, Germany, Belgium, Spain, England, Israel, Uganda, Mali, Russia, and India. He is professor at the Laica Eloy Alfaro de Manabí University. His research lines are Human and Sustainable Development; Educational Technology and language; Inclusive Entrepreneurship. His recent works are La investigación cualitativa rutas para la puesta en práctica (book); Learners' Attitudes toward Foreign Language Practice on Social Network Sites (article); and Motivation and Autonomy in Learning English as Foreign Language (article).

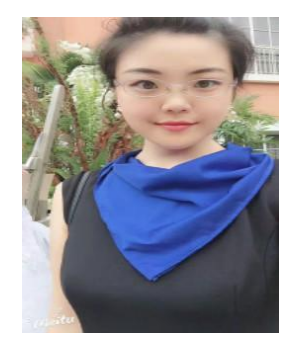

Jia H. Zou was born in Beijing the capital of China in the year 1993. She is getting her Bachelor's Degree in Tourism and Hotel Management at Universidad Técnica de Machala (UTMACH).

She has been working as a Chinese Language Tutor and also doing practical training with a travel agency and a five-star hotel. She collaborated in activities to improve the tourism in a small community in the province of El Oro. Currently, she is a member of a research group at UTMACH called ESP Researchers where she is conducting various studies related to her field.

Because English is an essential language for the Tourism industry, Ms. Zou completed and approved an online English Conversation Course organized by the United States Mission. She has also accomplished level 8 of English in a language institute at UTMACH. 